\title{
Alkol Kullanım Bozukluğu Olan Hastalarda ölüm Anksiyetesi ve İntihar Düşüncesi
}

\section{Death Anxiety and Suicidal Ideation in Patients with Alcohol Use Disorder}

\section{İsmet Esra Çiçek ${ }^{1}$ (D)}

1. Beyhekim Eğitim ve Araştırma Hastanesi, Psikiyatri Kliniği, Konya

\begin{abstract}
Objective: In this study, the death anxiety level of individuals with alcohol use disorder was compared with healthy controls and the relationship with suicidal ideation was evaluated.

Method: Twenty-two patients diagnosed with alcohol use disorder and 20 healthy controls with similar sociodemographic characteristics were included in the study. Suicidal ideation and death anxiety were evaluated in the participants.

Results: Death anxiety did not differ in individuals with alcohol use disorder compared to controls, and suicidal ideation was found to be high. Suicidal ideation and severity of alcohol use were found to be related.

Conclusion: The level of death anxiety was not high in patients with alcohol use disorder. However, our findings suggest a potential link between alcohol use disorder and suicidal ideation and suicide attempt.Studies with larger samples are needed to evaluate death anxiety and related factors in individuals with alcohol use disorder..

Keywords: Alcohol, death anxiety, suicide

Öz

Amaç: Çalışmada alkol kullanım bozukluğu olan bireylerde ölüm anksiyetesi düzeyi sağlıklı kontrollerle karşılaştııılmış ve intihar düşüncesi ile arasındaki ilişki değerlendirilmiş̧ir.

Yöntem: Çalışmaya 22 alkol kullanım bozukluğu tanısı almış hasta ve benzer sosyodemografik özellikler gösteren 20 sağlıklı kontrol alınmıştır. Katılımcılarda sosyodemografik ve klinik özellikler ile intihar düşüncesi ve ölüm anksiyetesi düzeyi değerlendirilmiştir.

Bulgular: Alkol kullanım bozukluğu olan hastalarda ölüm anksiyetesinin kontroller ile farkllık göstermediği, intihar düşüncesinin hastalarda yüksek olduğu bulundu. İntihar düşüncesi ile alkol kullanım şiddetinin ilişkili olduğu bulundu.

Sonuç: Alkol kullanım bozukluğu olan hastalarda ölüm anksiyetesi düzeyinin yüksek olmadığı bulunmuştur. Bununla birlikte bulgularımız alkol kullanım bozukluğu ile intihar düşüncesi ve intihar girişimi arasında potansiyel bir bağlantı olduğunu göstermektedir. Alkol kullanım bozukluğu olan bireylerde ölüm anksiyetesi ve ilişkili faktörleri değerlendiren daha geniş örneklemli çalışmalara intiyaç vardır.

Anahtar kelimeler: Alkol, ölüm anksiyetesi, intihar
\end{abstract}




\section{Giriş}

Alkol kullanım bozukluğu; etyolojisinde psikososyal ve genetik faktörlerin rol oynadığı, sonuçları itibariyle bireyi, yakınlarını ve toplumu etkileyen kronik bir bozukluktur. Araştırmalar, alkol kullanımı nedeniyle tedavi gören bireylerin yaklaşık üçte birinin, bir veya daha fazla anksiyete bozukluğu tanı kriterlerini karşıladığını göstermektedir(1). Cloninger'in tanımladığı tip I alkolizm gelişiminde önemli etkenlerin utangaç, anksiyöz ve karamsar kişilik yapısı olduğu bildirilmektedir (2). Strese maruziyet ve anksiyete duyarlıı̆ının da alkol alımını tetiklediği ve alkol kullanımının sürdürülmesinde etkili olduğu düşünülmektedir (3). İçme motivasyonunun alkolün anksiyolitik etkilerinden kaynaklanabileceği sıklıkla vurgulanmıştır. Davranışsal bir perspektiften alkolün hoş olmayan bir durum olan anksiyeteyi hafifletmesi, içme davranışı için olumsuz bir pekiştireç olarak görülür. NESARC verilerinin bir analizi, anksiyete bozukluğu semptomlarılla baş etmek için alkol kullandığını bildiren bireylerin, kalıcı alkol bağımılığı için yüksek risk altında olduğunu göstermiştir (4). Türkiye'de yapılan bir araştırmanın sonuçlarına göre yüksek anksiyete duyarlıı̆̆ olan kişiler, korku ve kaygılarından ya da korkularının grup içinde ortaya çıkmasından kaynaklanabilecek olumsuz yaşantılardan kaçınmak için alkol almaktadırlar (5).

Yazıı tarihin başlangıcından bu yana, insanın ölüm ile ilgili farkındalığının güçlü bir endişe kaynağı olduğu gösterilmiştir. Ölüm anksiyetesi çok sayıda psikolojik durumun gelişmesi ve devam etmesine katkısı olduğu düşünülerek transdiagnostik bir yapı olarak değerlendirilmiştir (6). Ölüm anksiyetesi ile ilgili yapılan çalışmalar değerlendirildiğinde çoğunun sağlıkı gruplarda olduğu görülmektedir. Farklı örneklemlerin kullanıldığı çalışmalarda; belirgin şekilde kadınların erkeklerden daha yüksek ölüm anksiyetesine sahip olduğu, yüksek eğitim düzeyi ve sosyoekonomik durumun ıımlı derecede daha düşük ölüm anksiyetesine neden olduğu, yüksek dindarlık derecesinin düşük ölüm anksiyetesine sahip olmak anlamına gelmediği, bedensel olarak sağlıklı olanlarda daha düşük ölüm anksiyetesi olduğu ve psikolojik problemlerin şiddeti ve sayısı arttıkça yüksek ölüm anksiyetesine sahip olunduğu bildirilmiştir (7-11).

Psikiyatride yapılan çalışmalara bakıldığında ölüm anksiyetesi açık bir şekilde sağlık anksiyetesinin merkezinde yer almakla beraber, travma sonrası stres bozukluğu, öznel fobi, agorafobi, panik bozukluk gibi birçok anksiyete bozukluğunda, obsesif-kompulsif bozuklukta, somatoform bozukluklarda, şizofrenide ve bipolar bozuklukta var olduğu belirtilmiş ve şiddeti araştııımışıı (12-15). Madde kullanım bozukluğu olan bireylerde ölüm anksiyetesinin araştırıldığı bir çalışmada ölüm anksiyetesi düzeyinin yüksek olduğu bildirilmiştir (16). İnsana özgü olan ölüme yönelik farkındalık kişide bilinçdışı bir dehşet hissi oluşmasına neden olur. Bu dehşet hissi ile başedebilmek için çeşitli savunma mekanizmaları kullanııır. Greenberg ve arkadaşları tarafından 1986 'da öne sürülen Dehşet Yönetim Kuramı'na göre kültürel dünya görüşlerini savunarak benlik saygısı kazanmanın, çocuk sahibi olmanın ve kalıcı eserler bırakmanın ölüm anksiyetesinin etkilerinden kişiyi koruduğu düşünülür. Ölüm anksiyetesi ile başedilememesinin ise çeşitli psikolojik bozuklukların oluşmasında etkili olabileceği öne sürülmüştür. Buna göre ölüm anksiyetesi tüm kaygıların kaynağı olarak tanımlanmıştır (17).

İntihar açısından alkol kullanım bozukluğu önemli bir risk faktörüdür. Alkol kullanım bozukluğu seyrinde komorbid psikiyatrik hastalıkların olması bu riski daha da artırmaktadır (18). Psikodinamik bakış açısıyla; alkol bağımlılarının kendilerine ve çevrelerine karşı gösterdikleri yıkıcı tutum gizli intihar eğilimlerinin belirtisi olarak değerlendirilmektedir. Bu kişilerin intihar eylemi yerine alkol kullanarak ölüme götüren daha dolaylı ve yavaş bir yol seçtikleri belirtilir. Literatürde intihar düşüncesi ve davranışı ile ölüm anksiyetesi arasındaki ilişkiyi inceleyen çalışmalar son derece kısıtıdır. Üniversite öğrencilerinde disosiyatif semptomlar, travma ve ölüm anksiyetesi arasındaki ilişkinin araştııılığı bir çalışmada geçmişte intihar girişimi olan kişilerde daha düşük ölüm anksiyetesi olduğu tespit edilmiştir(19).

Dehşet yönetim kuramına göre kişinin ölümle ilgili farkındalı̆ın oluşturduğu varoluşsal kaygııı yönetememesi psikolojik sorunlara zemin hazılamaktadır (20). Ölüm anksiyetesinın yönetilememesi de anksiyete düzeyini artırıp kişinin kendini alkol kullanımı ile tedavi etmeye çalışmasına ve intihar riskinde artışa neden olabilir. Tıbbi literatür incelendiğinde alkol kullanım bozukluğu ve ölüm anksiyetesi arasındaki ilişkiyi değerlendiren çalışmaların yetersiz olduğu görülmektedir. Bu çalışmada alkol kullanım bozukluğu 
olan bireylerde ölüm anksiyetesi düzeyinin sağlıkı kontrollerle karşılaştırıması ve ölüm anksiyetesi düzeyinin alkol kullanım bozukluğu şiddeti ve intihar ile ile ilişkisinin değerlendirilmesi amaçlanmışır

\section{Yöntem}

\section{Örneklem}

Bu prospektif kontrollü çalışmaya, 1 Temmuz 2020- 1 Eylül 2020 tarihleri arasında Konya Eğitim Araştırma Hastanesi AMATEM(Alkol ve Madde Bağımlııkları Tedavi Merkezi) kliniğine alkol bırakma talebi ile ardışık olarak başvurmuş, DSM-5'e (Amerikan Psikiyatri Birliği Ruhsal Bozuklukların Tanısal ve istatistiksel El Kitabı'nın beşinci baskısı) göre alkol kullanım bozukluğu tanısı alan, en az 2 haftadır alkol kullanımı olmayan, çalışma şartlarını kabul eden , 18-65 yaş arası hastalar dahil edilmiştir. Hastalardan rutin olarak alınan kan ve idrar tahlili ile alkol/madde kullanım bozukluğu doğrulanmıştır. Kontrol grubu olarak yaş, cinsiyet ve eğitim durumu açısından hasta grubu ile eşleştirilmiş 20 sağlıklı birey çalışmaya dahil edilmiştir. Sağlıkı kontroller psikiyatri polikliniğine genel muayene için başvuran ve herhangi bir psikiyatrik bozukluk ve fiziksel hastalığı olmayan kişilerden oluşturulmuştur. Çalışma süresince alkol kullanım bozukluğu tanısıyla başvuran 36 hastanın 1'i çalışmaya katımayı kabul etmediği için, 3'ü depresif bozukluk, 5'i anksiyete bozukluğu, 3'ü alkol yoksunluk belirtileri ve 2'si de ek madde kullanım bozukluğu olduğu için çalışmaya alınmamıştır. Sonuç olarak çalışma kriterlerini karşılayan 22 hasta ve 20 kontrol çalışmaya dahil edilmiştir.

Ek psikiyatrik bozukluk saptanan, fiziksel hastalık nedeniyle halen tedavi alan, alkol intoksikasyonu veya yoksunluk döneminde olan, alkol dışı madde kullanım bozukluğu olan, okur yazar olmayan ve mental yetersizlik veya bilişsel bozukluk saptanan hastalar çalışmaya dahil edilmemiştir. Kontrol grubu için ise halen psikiyatrik ve fiziksel hastalığın olması, alkol ve madde kullanım bozukluğu olması, okur yazar olmamak ve mental yetersizlik veya bilişsel bozukluk saptanması dışlama kriterleri olarak belirlenmiştir.

\section{İşlem}

Çalışmanın uygulanabilmesi için KTO Karatay Üniversitesi Tıp Fakültesi Illaç ve Tıbbi cihaz dışı araştırmalar Etik Kurulu'ndan 19.06.2020 tarihli 2020/030 karar sayılı etik kurul onayı alınmıştır. Hasta ve sağıklı kontrollerden yazılı bilgilendirilmiş onam alındıktan sonra araştırmacı tarafından hazırlanmış sosyodemografik özellikleri ve alkol/madde kullanım özelliklerini içeren yarı yapılandııımış bir veri formu uygulanmıştır. Çalışmaya dahil edilen hastalara Michigan Alkolizm Tarama Testi, Templer'in Ölüm Anksiyetesi Ölçeği (ÖKÖ) ve İntihar Düşüncesi Ölçeği (IDÖ), sağlıkı kontrollere ise ÖKÖ ve iDÖ uygulanmışıır.

\section{Veri Toplama Araçları}

\section{Michigan Alkolizm Tarama Testi (MATT)}

Bir kişinin alkol kullanım sorunlarıyla karşılaşıp karşılaşmadığını, varsa düzeyini ölçmek için kullanılır. Birinci basamak sağlık hizmetine başvuranlara, alkol bağımlılı̆ı ile ilgili sorunu olduğu düşünülen kişilere uygulanabilir. Hastaların doldururken kendilerine en çok uyan seçeneği işaretlemeleri istenir. Değişik puanlar verilen 25 sorudan oluşur. Puanlara göre 0-4 sorunsuz içici, 5-9 alkol kötüye kullanımı, 10 ve üzeri alkol bağımılı̆̆ı şeklinde değerlendirilir. Gibbs (21) tarafından geliştirilen testin orjinal Cronbach alfa değeri 0.87, Coşkunol ve arkadaşları (22) tarafından yapılan Türkçe geçerlik ve güvenirlik çalışmasının Cronbach alfa değeri ise 0.91 bulunmuştur. Testin kesme noktası 5-9 olarak önerilmiştir.

\section{Templer'in Ölüm Anksiyetesi Ölçeği (ÖKÖ)}

1970 yllında Templer tarafından geliştirilmiş olan bu ölçek bireyin kendi ölümü ve ölüm riski ile ilgili kaygı ve korkularını ölçen, 15 maddelik, doğru-yanlış şeklinde yanıtlanan bir ölçektir (23). Ölçekteki ilk 9 maddeye ve son soruya verilen her bir 'evet' yanıtı için ' 1 ', 'hayır' yanıtı için ' 0 ' puan, diğer 5 maddeye verilen her bir 'hayır' yanıtı için '1', 'evet' yanıtı için '0' puan alınmaktadır. Toplam skor 0-15 arasında 
olabilir. Yüksek puan artmış ölüm anksiyetesini gösterir. Arapça ve İspanyolcaya çevrilmiş, ülkemizde geçerlik ve güvenirlik çalışması 2008 yılında Akça tarafından yapıımıştır (24). Testin orijinal versiyonunun Cronbach alfa değeri 0.83 iken, Türkçe versiyonunun Cronbach alfa değeri 0.79'dur.

\section{İnthhar Düşüncesi Ölçeği (iDÖ)}

Özsaygıda azalma olup olmadığı, öfkenin kontrol edilip edilemediği, umutsuzluk ve karamsarlık, ölüm fikirleri ve isteği, kendine zarar verme isteği, başkalarına zarar verme isteği, suçluluk duygusu gibi intihar girişimiyle bağlantılı değişkenleri ölçmek ve değerlendirmek için Levine ve arkadaşları tarafından geliştirilmiştir (25) .17 sorudan oluşan bir kendini değerlendirme ölçeğidir. Formun amacı intihar düşüncesinin şiddetini belirlemektir. Ölçekten alınabilecek toplam puan 0- 17 arasında değişmektedir. "Evet" şeklindeki cevaplar "1" puan, " hayır" şeklindeki cevaplar "0" puan olarak kabul edilmektedir. Daha yüksek puanlar, kişide daha ciddi ve belirgin intihar düşüncesi olduğu anlamına gelmektedir. İntihar düşüncesi Ölçeği'nin Türkçe versiyonunun geçerlik ve güvenirlik araştırması 1995 yılında yapılımıştır (26). Testin Türkçe versiyonunun Cronbach alfa değeri 0.88'dur

\section{Veri Analizi}

İstatistik analizler SPSS programının 20.0 versiyonu ile yapılmıştır. Normal dağı̆ım gösteren yaş, eğitim süresi, ÖKÖ ve IDÖ puanlarının değerlendirilmesinde bağımsız gruplar için t testi; medeni durum, çalışma durumu, intihar girişimi, kendine zarar verme ve aile öyküsünü içeren kategorik değişkenler için Ki-kare testi kullanıımıştır. Hastaların klinik ve sosyodemografik özellikleri ile ÖKÖ, IDÖ ve MATT ölçeği puanlarının korelasyonları için Pearson korelasyon testi kullanılmıştır. Analizlerde anlamlılık düzeyi olarak $\mathrm{P}<0.05$ alınmıştır.

\section{Bulgular}

Hasta ve kontrollerin sosyodemografik özellikleri Tablo-1'de verilmiştir. Tabloda görüldüğü gibi hasta ve kontroller arasında yaş, eğitim durumu, medeni durum ve çalışma durumu açısından fark görülmemiştir (sırasıyla p değerleri:0,325; 0,774; 0,261; 0,269). İntihar girişimi, kendine zarar verme davranışı ve ailede alkol kullanım öyküsü ise hasta grubunda kontrol grubuna göre anlamlı düzeyde yüksek saptanmıştır (sırasıyla $p$ değerleri 0,$001 ; 0,023 ; 0,013$ ). iDÖ ölçek puanı alkol kullanım bozukluğu olan bireylerde anlamlı düzeyde yüksek bulunurken $(p=0,000)$, ÖKÖ puanının kontrollerden farkı olmadığı saptanmıştır $(p=0,417)$.

Tablo-1. Hasta ve kontrollere ait sosyodemografik özellikler ve ölçek skorları

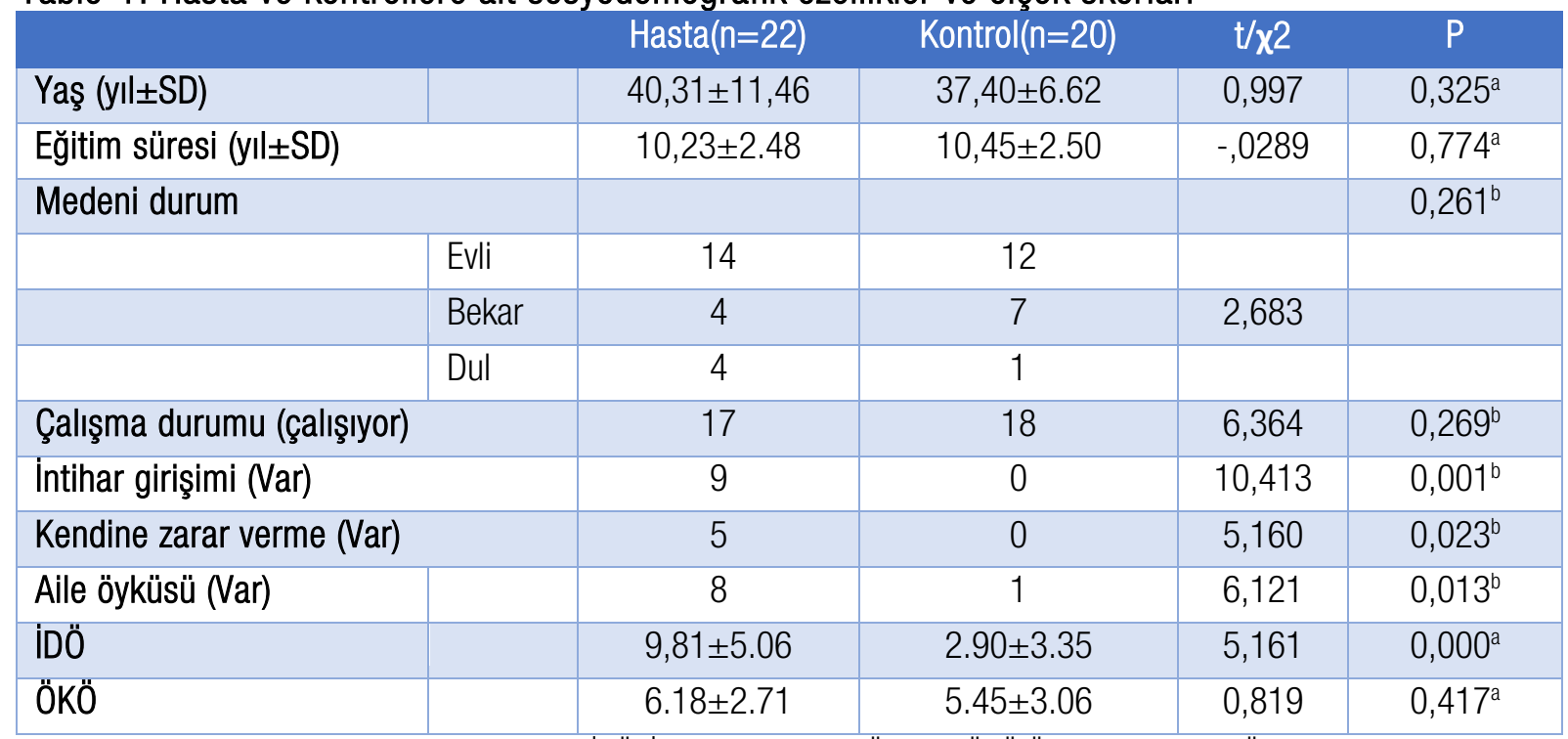

${ }^{a}$ Independent simple t test. ${ }^{b}$ Chi-Square Test iDÖ: İntihar Düşüncesi Ölçeği, ÖKÖ:Ölüm Anksiyetesi Ölçeği 
Hastalara ait alkol kullanım bozukluğu ile ilgili klinik özellikler ise Tablo-2'dedir. Hastaların alkol kullanımına başladıkları yaş ortalamasının 20.00 \pm 5.36 yıl olduğu, yaklaşık $19.63 \pm 11.75$ yıldır alkol kullanımını sürdürdükleri, ortalama $2.13 \pm 2.23$ defa bırakma girişimlerinin olduğu ve hastalarda MATT skor ortalamasının $30.18 \pm 9.29$ olduğu saptanmıştır.

Tablo-2.Hastalara ait alkol kullanım bozukluğu ile ilgili klinik özellikler

\begin{tabular}{|l|c|}
\hline Alkol kullanımına başlama yaşı(yll) & Hasta $(\mathrm{n}=22)$ \\
\hline Alkol kullanım süresi( $\mathrm{yIl})$ & $20.00 \pm 5.36$ \\
\hline Bırakma girişimi sayısı & $19.63 \pm 11.75$ \\
\hline Hastaneye yatış sayısı & $2.13 \pm 2.23$ \\
\hline MATT skoru & $1.09 \pm 1.54$ \\
\hline
\end{tabular}

MATT: Michigan Alkolizm Tarama Testi

Tablo-3'te görüldüğü gibi ÖKÖ ile her hangi bir değişken arasında ilişki saptanmamıştır. Alkol kullanım şiddetini ölçen MATT ile İDÖ arasında anlamlı ilişki saptanmıştır ( $p=0.041)$.

Tablo-3. Hastaların klinik özellikleri ile ölçekler arasındaki korelasyon analizi

\begin{tabular}{|c|c|c|c|c|c|}
\hline \multirow{3}{*}{ Yaş } & & yaş & IDÖ & ÖKÖ & MATT \\
\hline & $r$ & & 0,088 & 0,211 & 0,110 \\
\hline & $p$ & & 0,581 & 0,179 & 0,627 \\
\hline \multirow[t]{2}{*}{ Alkol başlama yaşı (yıl) } & $r$ & 0,197 & $-0,088$ & 0,098 & $-0,411$ \\
\hline & $p$ & 0,378 & 0,698 & 0,665 & 0,058 \\
\hline \multirow[t]{2}{*}{ Alkol kullanım süresi (yıl) } & $r$ & 0,883 & 0,021 & 0,302 & 0,316 \\
\hline & $p$ & .000 & 0,925 & 0,172 & 0,152 \\
\hline \multirow[t]{2}{*}{ Sigara başalama yaşı (yıl) } & r & 0,414 & 0,192 & 0,246 & $-0,171$ \\
\hline & $p$ & 0,062 & 0,403 & 0,282 & 0,458 \\
\hline \multirow[t]{2}{*}{ IDÖ } & r & 0,088 & & 0,016 & 0,439 \\
\hline & $p$ & 0,581 & & 0,918 & 0,041 \\
\hline \multirow[t]{2}{*}{ ÖKÖ } & $r$ & 0,211 & 0,016 & & 0,129 \\
\hline & $p$ & 0,179 & 0,918 & & 0,568 \\
\hline \multirow[t]{2}{*}{ MATT } & r & 0,110 & 0,439 & 0,129 & \\
\hline & $p$ & 0,627 & 0,041 & 0,568 & \\
\hline
\end{tabular}

IDÖ: Intihar Düşüncesi Ölçeği, ÖKÖ:Ölüm Anksiyetesi Ölçeği, MATT: Michigan Alkolizm Tarama Testi

\section{Tartışma}

Ulaşabildiğimiz kadarıyla bu çalışma, alkol kullanım bozukluğu olan hastalarda ölüm anksiyetesi düzeyini değerlendiren ilk kontrollü çalışmadır. Hipotezimizin aksine çalışma sonucunda alkol kullanım bozukluğu olan hastalarda kontrollere göre ölüm anksiyetesi düzeyi yüksek bulunmadı. Alkol kullanım bozukluğu olan hasta grubunda kontrollere göre intihar düşüncesi düzeyi, intihar girişimi ve kendine zarar verme yüksek saptandı. İntihar düşüncesi ile alkol kullanım şiddeti arasında pozitif yönde anlamlı ilişki olduğu bulundu.

Abdelhalek ve arkadaşlarının Arap Ölüm Anksiyetesi Ölçeği kullandıkları, şizofreni ve anksiyete bozukluğu hastalarının ve sadece erkek bağımlıların her iki cinsiyetten sağlıklı kontrollerle karşılaştııılığı çalışmada, bağımlı grup ile sağlıklı kontroller arasında anlamlı bir fark saptanmadığı bildirilmiştir. Burada bağımlı grubun hangi maddeleri kullandığı ve madde kullanım şiddeti net olarak ifade edilmemiş, hastaların alkol kullanıp kullanmadıkları da belirtilmemiştir. (27). Yaş ortalaması 36.8 olan 85 madde kullanım bozukluğu tanılı hastanın değerlendirildiği kontrolsüz bir çalışmada ise ölüm anksiyetesi düzeyi, aynı ölçeği kullanan başka popülasyonlarda yapılmış çalışmalarla karşılaştırlarak yüksek olarak bildirilmiştir (28). Önceki çalışmalarda kullanılan ölçeklerin farkılığı ve hasta popülasyonunun alkol dışı bağımlı gruplarını 
içermesinden dolayı bulgularımız farklıık gösteriyor olabilir. Bağımlılık bir grup hastalık olarak değerlendirilse de alkol, sedatif hipnotik, eroin gibi farklı maddelerin tercih edilmesinde farklı kişilik özellikleri ve genetik yatkınlıkların etkisi ve kullanılan maddenin farkı psikolojik etkileri olabilir. Bunula birlikte hastaların alkol kullanım bozukluğu açısından tedavi ile remisyon halinde olmaları da ölüm anksiyetesi düzeylerini etkilemiş olabilir. Ayrıca çalışmada tedavi başvurusu olan hastaların seçilmiş olması, bu kişilerin alkol ile ilgili daha fazla sosyal ve mesleki alanlarda daha fazla sorun yaşayan kişiler olmasına neden olmuş olabilir.

Dehşet yönetim kuramında önerildiği gibi ölüme yönelik farkındalığın, günlük yaşamı, davranışları, kararları ve nihayetinde kişinin psikolojik sağıı̆ını etkileyen bir yönü vardır. Bu varoluşsal kaygının yönetilememesi psikolojik sorunlara yol açabilir. Çocukluk çağı travmaları, bağlanma sorunları, olumsuz yaşam deneyimleri anksiyete tamponlama sistemlerinin gelişimini olumsuz etkileyerek ölüm anksiyetesi ile başetmeyi güçleştirir(29). Ölüm anksiyetesi ile başedememe alkol madde kullanım oranlarını ve intihar riskini artırabilir. Çalışmamızın sadece erkek hastaları içermesi ve örneklemin küçük olması sonuçlarımızı etkilemiş olabilir. Bu konuda yapılacak geniş örneklemli ve her iki cinsiyeti içeren çalişmalara intiyaç vardır.

Alkol kişide impulsif ve agresif davranış oluşmasına en sık neden olan psikoaktif maddeler arasındadır. Dünya Sağlık Örgütü verilerine göre tüm tamamlanmış intiharların \%22'si alkol ile ilişkili bulunmuştur. Alkol kullanım bozukluğu olan bireylerde intihar düşüncesi ve intihar girişimi oranlarının yüksek olduğuna dair yapılan çalışmalar mevcuttur (30). Kronik alkol kullanım bozukluğu olmasa da intihar girişimini hemen öncesinde akut alkol kullanım oranlarının yüksek olduğu bildirilmiştir (31). Çalışmamızın sonuçlarından biri de alkol kullanım şiddeti ile intihar düşüncesi arasında ilişki olmasıdır. Üniversite öğrencilerinde yapılmış yakın zamanlı bir çalışmada bulgularımızla uyumlu olarak intihar düşüncesi ile alkol kullanım şiddetinin ilişkili olduğu saptanmış ve bu durum anksiyete duyarılığı ile açıklanmıştır (3). Yalom, intihar bilincinin hayatın sona ermesinin inkarına dayanan bir çeşit reaksiyon formasyon olduğunu, intiharın ölüm anksiyetesi için paradoksal bir davranış işareti olarak görülebileceğini savunmaktadır (32).

Çalışmamızda yaş ile ölüm anksiyetesi arasında bir ilişki bulunmamıştır. İlk bakışta ilerleyen yaşlarda ölüme yaklaşmakla ölüm anksiyetesinin artacağı düşünülebilir. Bu beklentiye rağmen yaş ile ölüm anksiyetesi arasında farkı çalışmalarda farkı sonuçlar elde edilmiştir. Türkiye'de yapılmış bir diğer çalışmada ise 16 yaş üstü bireyler arasında ölüm anksiyetesi değerlendirildiğinde 60 yaş üzerinde ölüm anksiyetesinın arttı̆̆ı bildirilmiştir (33). Huzurevinde yaşayan 120 yaşı bireyin değerlendirildiği bir çalışmada 60-64 yaş arası bireylerin 70 yaş üstüne göre ölüm anksiyetesinın daha yüksek olduğu bildirilmiştir(34). Bu çalısmada ayrıca kadınların ölüm anksiyetesi erkekler göre yüksek bulunmuştur. Kadın cinsiyette ölüm anksiyetesinın daha yüksek olduğunu bildiren çalışmalar mevcuttur (27). Ilerleyen yaşla birlikte artan kronik ve sistemik hastalıklar da ölüm anksiyetisi düzeyini etkileyebilmektedir. Çalışma örneklemimizin sadece erkek hastalardan oluşması ve ek sistemik hastalıkların dışlanmış olması nedeniyle ölüm anksiyetesi düzeyi daha düşük bulunmuş olabilir.

Yüksek ölüm anksiyetesi sergileyen bireylerin genel kaygı ölçeklerinden, özellikle sürekli anksiyete açısından daha yüksek puan aldıkları ortaya konmuştur(35). Alkol kullanım bozukluğu olan bireylerde anksiyöz kişilik yapısı ve anksiyete birlikteliğinin yüksek olduğu bilinmektedir. Obsesif kompulsif bozukluk, özgül fobiler, panik bozukluk ve sağlık anksiyetesi bozukluğu ölüm anksiyetesinin mükerrer şekilde yüksek bulunduğu hastalık gruplarıdır $(13,36,37)$ Çalışmamızda psikiyatrik ek tanısı olan hastaların dışlanmış olması ölüm anksiyetesi düzeylerinin daha düşük saptanmasına neden olmuş olabilir.

Çalışma popülasyonunun küçük olması, sadece erkek hastalardan oluşması, subklinik anksiyete ve depresyon şiddetinin değerlendirilmemiş olması, kendi bildirim ölçeklerinin kullanılmış olması, kesitsel bir çalıma olması ve kişilik özelliklerinin değerlendirilmemiş olması sınırlııklarımız arasındadır.

Sonuç olarak, çalışmamızda alkol kullanım bozukluğu olan hastalarda ölüm anksiyetesi düzeyinin yüksek olmadığı bulunmuştur. Bununla birlikte bulgularımız alkol kullanım bozukluğu ile intihar düşüncesi ve intihar girişimi arasında potansiyel bir bağlantı olduğunu göstermektedir. Bu nedenle alkol kullanım bozukluğu 


\section{Bağımlılık Dergisi - Journal of Dependence}

olan tüm hastaların intihar düşüncesi açısından taranması önerilmektedir. Ayrıca bulgularımız daha büyük bir örneklem üzerinde ve çalışmamızın sınırıılıklarını da dikkate alan çalışmalarca teyit edilmelidir.

\section{Kaynaklar}

1. Vorspan F, Mehtelli W, Dupuy G, et al. Anxiety and substance use disorders: co-occurrence and clinical issues. Curr Psychiatry Rep 2015; 17(2): 4-11.

2. Cloninger CR, Sigvardsson S, Bohman M. Type I and Type II alcoholism: An update. Alcohol Health Res World 1996; 20(1): 18-23.

3. Paulus DJ, Capron DW, Zvolensky MJ. Understanding hazardous drinking and suicidal ideation and suicide risk among college students: anxiety sensitivity as an explanatory factor. Cogn Behav Ther 2020; doi: 10.1080/16506073.2020.1840622.

4. Menary KR, Kushner MG, Maurer E, Thuras P. The prevalence and clinical implications of self-medication among individuals with anxiety disorders. J Anxiety Disord 2011; 25(3): 335-339.

5. Çakmak SŞ. Psychometric properties of anxiety sensitivity index-revised and the relationship with drinking motives and alcohol use in Turkish university students and patients: Middle East Technical University, Department of Psychology, 2006.

6. Yalom ID, Babayiğit Zi. Varoluşçu Psikoterapi: Kabalcı Yayınevi; 2001.

7. Furer P, Walker JR. Death anxiety: A cognitive-behavioral approach. J Cogn Psychother 2008; 22(2): 167-182.

8. Fortner BV, Neimeyer RA. Death anxiety in older adults: A quantitative review. Death Stud 1999; 23(5): 387411.

9. Eshbaugh E, Henninger W. Potential mediators of the relationship between gender and death anxiety. Individ Differ Res 2013; 11(1): 22-30.

10. Russac R, Gatliff C, Reece M, Spottswood D. Death anxiety across the adult years: An examination of age and gender effects. Death Stud 2007; 31(6): 549-561.

11. Menzies RE, Sharpe L, Dar-Nimrod I. The relationship between death anxiety and severity of mental illnesses. $\mathrm{Br}$ J Clin Psychol 2019; 58(4): 452-467.

12. Starčević V. Body as the source of threat and fear of death in hypochondriasis and panic disorder. Psihijatrija danas 2007;39(1): 73-82.

13. Menzies RE, Dar-Nimrod I. Death anxiety and its relationship with obsessive-compulsive disorder. J Abnorm Psychol 2017; 126(4): 367-377.

14. Vail III KE, Reed DE, Goncy EA, Cornelius T, et al. Anxiety buffer disruption: Self-evaluation, death anxiety, and stressor appraisals among low and high posttraumatic stress symptom samples. J Soc Clin Psychol 2020; 39(5): 353-382.

15. Khanna N, Khanna R, Sharma R. A study on death anxiety. J Pers Clin Stud 1988; 4(1): 47-51.

16. Daradkeh F, Moselhy HF. Death anxiety (Thanatophobia) among drug dependents in an Arabic psychiatric hospital. Am J Drug Alcohol Abuse 2011; 37(3): 184-188.

17. Arndt J, Routledge C, Cox CR, Goldenberg JL. The worm at the core: A terror management perspective on the roots of psychological dysfunction. Appl Prev Psychol 2005; 11(3): 191-213.

18. Çelik S, Demirbaş H, Illhan ï̈, Doğan YB. Alkol bağımlıı̆ında intihar olasilığı ile depresyon, anksiyete ve kişilik bozukluğu ek tanıları arasındaki ilişki. Bağımlıık Dergisi 2002; 3(1): 17-20.

19. Boysan M. Üniversite öğrencilerinde disosiyatif yaşantılar, travma ve ölüm anksiyetesi: Yüzüncü Yı Üniversitesi öğrencileri üzerine bir çalışma Yüksek lisans Tezi, Van: Yüzüncü Yıl Üniversitesi, Sağlık Bilimleri Enstitüsü, 2005.

20. Doğulu C, Uğurlu NS. Dehşet Yönetimi Kuramı üzerine bir derleme. Türk Psikoloji Yazıları 2015; 18(35): 33-47.

21. Gibbs LE. Validity and reliability of the Michigan alcoholism screening test: a review. Drug Alcohol Depend 1983; 12(3): 279-85.

22. Coskunol H, Bagdiken I, Sorias S, Saygili R. Michigan alkolizm tarama testinin geçerliliği. Ege Tıp Dergisi 1995; 34(1): 15-18.

23. Templer DI. The construction and validation of a Death Anxiety Scale. J Gen Psychol 1970; 82(2): 165-177.

24. Akça F, Köse İA. Ölüm Anksiyetesi Ölçeğinin uyarlanması: geçerlik ve güvenirlik çalışması. Klinik Psikiyatri Dergisi 2008; 11(1): 7-16.

25. Levine S, Ancill Ru, Roberts A. Assessment of suicide risk by computer-delivered self-rating questionnaire: preliminary findings. Acta Psychiatr Scand 1989; 80(3): 216-220.

26. Dilbaz N, Holat $H$, Bayam $G$, Tüzer $T$, ve ark. İtihar düşüncesi ölçeğinin geçerlilik ve güvenirliği. 31. Ulusal Psikiyatri Bilimler Kongresi Bilimsel Çalışma Kitabı. 1995:40-41. 


\section{Bağımlılık Dergisi - Journal of Dependence}

27. Abdel-Khalek AM. Death anxiety in clinical and non-clinical groups. Death Stud 2005; 29(3): 251-259.

28. Daradkeh F, Moselhy HF. Death Anxiety (Thanatophobia) among drug dependents in an Arabic Psychiatric Hospital . Am J Drug and Alcohol Abuse 2011; 37(3): 184-188.

29. Maxfield M, John S, Pyszczynski T. A terror management perspective on the role of death-related anxiety in psychological dysfunction. J Humanist Psychol 2014; 42(1): 35-53.

30. Lasota D, Al-Wathinani A, Krajewski P, Mirowska-Guzel D, et al. Alcohol and the risk of railway suicide. Int $\mathrm{J}$ Environ Res Public Health 2020; 17(19): 7003.

31. Kaplan MS, Huguet N, McFarland BH, et al. Use of alcohol before suicide in the United States. Ann Epidemiol 2014; 24(8): 588-92.

32. Yalom ID. Staring at the sun: Overcoming the terror of death. Humanistic Psychologist 2008; 36(3-4): 283-297.

33. Erdoğdu MY, Özkan M. Farkı dini inanışlardaki bireylerin ölüm kaygıları ile ruhsal belirtiler ve sosyo-demografik değişkenler arasındaki ilişkiler.Inönü Üniversitesi Tıp Fakültesi Dergisi 2007; 14(3): 171-179.

34. Şenol C. Ankara Ilinde kurumlarda yaşayan yaşıllarda ölüme ilişkin kaygı ve korkular. Yüksek Lisans Tezi, Ankara: Ankara Üniversitesi Sosyal Bilimler Enstitüsü, 1989.

35. Neimeyer RA, Wittkowski J, Moser RP. Psychological research on death attitudes: An overview and evaluation. Death Stud 2004; 28(4): 309-40.

36. Strachan E, Schimel J, Arndt J, et al. Terror mismanagement: Evidence that mortality salience exacerbates phobic and compulsive behaviors. Pers Soc Psychol Bull 2007; 33(8): 1137-1151.

37. Furer $P$, Walker JR, Stein MB. Treating Health Anxiety and Fear Of Death: A Practitioner's Guide: Springer Science \& Business Media; 2007. 